\title{
Analysis of Efficiency Of KDT-OAT and Removal Preparations on The Recovery of Pulmonary Tuberculosis
}

\author{
Kristin Berlianta Duha ${ }^{1 *}$, Sri Lestari Ramadhani Nasution ${ }^{2}$, Ermi Girsang ${ }^{3}$, Tan \\ Suyono ${ }^{4}$ \\ ${ }^{1}$ Magister Student of Magister Public Health, Faculty of Medicine, University of Prima \\ Indonesia \\ ${ }^{2,3,4}$ Magister Public Health, Faculty of Medicine, University of Prima Indonesia \\ ${ }^{*}$ Corresponding author: \\ Email: kristinberliantaunpri@gmail.com
}

\begin{abstract}
.
Tuberculosis is one of the 10 most common causes of death and is the single most common cause of infection and causes illness every year in millions of people. The etiology of tuberculosis is the bacteria Mycobacterium tuberculosis and Mycobacterium bovis. These germs have a size of 0.5-4 microns x 0.3-0.6 microns with thin rods, straight or slightly bent, granular or have no sheath, but have a thick outer layer consisting of lipoids (especially mycolic acid). Based on data from the Riset Kesehatan Dasar in 2018 conducted by the Kementerian Kesehatan RI, the prevalence rate of pulmonary TB by doctors in Indonesia in 2018 was the same as in 2013 which was $0.4 \%$. Based on the OAT guidelines used in Indonesia, there are two OAT drug preparations, namely OAT-KDT or (FDC) and the Kombipak package. Comparison of the efficacy of this drug in curing pulmonary TB also varies. The purpose of this research is to determine the efficacy of KDT-OAT and removal preparations on the cure rate of pulmonary $T B$. This type of research is a retrospective cohort study, which is a time-period approach. This study was conducted in October-November 2020. There was no significant difference in treatment outcomes in pulmonary TB patients who received OAT-KDT or OATrelease preparations.
\end{abstract}

Keywords: Pulmonary Tuberculosis, OAT-KDT, OAT removal preparations.

\section{INTRODUCTION}

Pulmonary Tuberculosis (TB) is a lung infectious disease that is airborne with the causative agent in the form of Mycobacterium Tuberculosis. The main source of infection for this infection is pulmonary TB patients with positive examination results and not taking therapy. These microorganisms mainly infect the lungs, but can also affect other organs (Extra Pulmonary) (Rab, 2017; Adane et al., 2020).

This disorder can develop especially in people with low immune systems. Expectation of Mycobacterium tuberculosis, (the causative agent of TB) by adults with active lung disease promotes ongoing transmission of the disease. In an effort to prevent the spread of this disease in 1908 BCG vaccine was found to prevent transmission of this disease and in 1943 OAT drugs were introduced to eradicate pulmonary TB. However, the use of the BCG vaccine as a prevention of this disorder 
was only carried out in the middle of the 20th century. Ironically, the efficacy of this vaccine is still unclear and does not show good efficacy in areas with a high incidence of pulmonary TB (Fogel, 2015; Jacobs et al., 2016; Adane et al., 2020).

Six countries with prominent TB cases with large number of cases in 2014 were India, Indonesia, China, Nigeria, Pakistan and South Africa, these countries and four other countries (Bangladesh, Philippines, DR Congo, and Ethiopoia) which became top ten countries with TB disease. India, Indonesia and China alone were responsible for 43\% of global cases in 2014 (Jacobs et al., 2016; World Health Organization, 2016; Adane et al., 2020).

Based on data from the Riset Kesehatan Dasar in 2018 conducted by the Kementerian Kesehatan RI, there are two provinces with a low prevalence of pulmonary TB, namely Bali and Bangka Belitung, namely 0.1 percent and two provinces with the highest prevalence of pulmonary TB, namely Banten and Papua, which is 0.8 percent. Meanwhile, the prevalence of pulmonary TB in North Sumatra is 0.3 percent. All of these data are cases of pulmonary TB diagnosed by both specialists and general practitioners (Kementerian Kesehatan RI, 2019).

Based on the OAT guidelines used in Indonesia, there are two OAT drug preparations, namely OAT-KDT or (FDC) and the Kombipak package. OAT-KDT or Fixed-Dose Combination Anti-Tuberculosis Drugs are provided for category-1 and category-2 treatment and are packaged in one package for one patient. Meanwhile, the kombipak package is a removal preparation package consisting of Isoniazid, Rifampicin, Pyrazinamide and Ethambutol which is packaged in blister form, and is provided for the treatment of patients experiencing side effects of OAT-KDT (Kementerian Kesehatan RI, 2016).

Comparison of the efficacy of this drug in curing pulmonary TB also varies. Several studies have been conducted to compare the effectiveness of this drug as reported by Al-Shaer et al. (2017) in 148 respondents at two public hospitals in Qatar reported that there was a significant difference in the time required for the conversion of sputum results to negative between respondents who received FDC and separate doses in the group of respondents suffering from diabetes where it took longer for respondents who received the kombipak package (Al-Shaer et al., 2017). However, other studies reported different results, where there was no difference in the efficacy of FDCs and loose preparations (Albanna et al., 2013). Meanwhile, other studies also reported similar results in the type of Extra Pulmonary TB, where there was no difference in the efficacy of the two dosage forms. However, in Extra Pulmonary TB, it was shown that patients receiving OAT therapy had a higher incidence of paresthesia, retrobulbar neuritis, ulceration, and vomiting compared to patients receiving FDC (Ayed et al., 2018).

From the initial survey conducted by researchers, the number of pulmonary TB patients who received outpatient treatment at Mitra Sejati Hospital in Medan was 124 people. This number represents the total number of patients for the last 6 months. With the high incidence of pulmonary TB in various places and there are several types of pulmonary TB drug preparations, it is necessary to conduct a study to determine the comparison of the effectiveness of OAT preparations in the form of FDC and removal preparations in pulmonary TB patients. 


\section{METHODS}

This type of research is a retrospective cohort study, which is a time-period approach. In this study, the subject was observed for a certain period of time on risk factors and then assessed the effects that occurred in the past. This research was conducted at Mitra Sejati Hospital Medan, with the consideration that the hospital had a TB clinic. This research was conducted in October-November 2020 by taking data from the medical records of patients who had been treated in 2019 until mid-2020 at Mitra Sejati Hospital.

The target population of this study were all outpatients diagnosed with pulmonary TB in 2019-2020. Sampling in this study was total sampling, where the entire population reached in this study was taken as a sample. However, the number of samples used in this study was at least 200 people.

The data collected in this study is secondary data obtained through the medical records of patients with TB diagnoses during 2019, which will then be recapitulated and analyzed according to the data analysis in this study. All data analysis carried out in this study was carried out with IBM SPSS Statistics 25 Software.

\section{RESULT AND DISCUSSION}

In this study, the majority of TB patients came from the early and late elderly age groups, namely 104 people (34\%) and 68 people (34\%). This is different from the results of a study conducted by the Ministry of Health of the Republic of Indonesia in 2018, where the highest prevalence of TB was found in the 65-74 year age group at $1.0 \%$, followed by the 55-64 year age group at $0.8 \%$. This difference is due to differences in the study population, the current study uses a population group in the form of all pulmonary TB patients at Mitra Sejati Amplas Hospital. Meanwhile, research conducted by the Kementrian Kesehatan RI was conducted on all pulmonary TB patients in Indonesia, both those seeking treatment at hospitals and other health facilities (Kementrian Kesehatan RI, 2019).

Based on the results of research conducted by the Kementrian Kesehatan RI in 2018 , where the prevalence of pulmonary TB was mostly found in men, namely $0.5 \%$ while the remaining $0.4 \%$ were women. However, this study showed different results, where pulmonary TB patients at Mitra Sejati Amplas Hospital were more common in women than men. This could be related to differences in the study population and medication adherence. According to data from the Riset Kesehatan Dasar in 2018, women $(70.1 \%)$ take medicine more regularly than men $(68.5 \%)$ (Kementrian Kesehatan RI, 2019).

Sitepu et al. (2018) reported that the majority of pulmonary TB patients at dr. The majority of Esnawan Antariksa have a body mass index within normal limits of $18.5-24.9 \mathrm{~kg} / \mathrm{m} 2$ as many as 42 people $(66.67 \%)$. The results of this study are in line with the results of the current study, where the majority of pulmonary TB patients at Mitra Sejati Amplas Hospital have a body mass index within normal limits of 88 people (44\%) (Sitepu et al., 2018).

The results of this study show results that are in line with several studies that have been conducted by Al-Shaer et al. (2017) and Sitepu et al. (2018). Both reported 
that the majority of patients with pulmonary $\mathrm{TB}$ had no comorbidities, but the majority of patients with pulmonary TB had diabetes mellitus. Al-Shaer et al. (2017) reported that as many as 33 people $(22.30 \%)$ of Pulmonary TB patients who underwent Pulmonary TB treatment at two different General Hospitals in Qatar experienced Diabetes Mellitus. While Siteput et al. (2018) reported that 12 people $(19.05 \%)$ patients with pulmonary TB at dr. Esnawan Antariksa has a co-morbidity in the form of pulmonary TB (Al-Shaer et al., 2017; Sitepu et al., 2018).

The results of this study are slightly different from the results of research conducted by Al-Shaer et al. (2017). Al-Shaer et al. (2017) reported that pulmonary TB patients at two different General Hospitals in Qatar had an average seroconversion time of 29.9 days for pulmonary TB patients receiving OAT, while pulmonary TB patients receiving removable preparations had an average seroconversion time of 35.6 days. The difference in the results of this study was due to the difference in the seroconversion time scale of the previous study and the current study. Al-Shaer et al. (2017) measure the time of seroconversion in days while in the current study it is measured in months (Al-Shaer et al., 2017; Sitepu et al., 2018).

The results of the current study are in line with the results of previous research conducted by Sitepu et al. (2018), Al-Shaer (2017), and Lienhardt et al. (2011). The results of the current study report that there is no difference in the percentage of seroconversion from each group of OAT preparation types in pulmonary TB patients at dr. Esnawan Antariksa after 2 weeks of treatment, this can be seen from the number of patients who experienced seroconversion in pulmonary TB patients with KDT-OAT treatment as much as $83.3 \%$ and in pulmonary TB patients with loose dosage treatment as many as $78.7 \%$ ( $\mathrm{P}$ value $=0.694)$. Another study conducted by Al-Shaer (2017) reported that there was no difference in the average time of seroconversion in patients who received OAT-KDT or loose preparations at two different General Hospitals in Qatar, this can be seen from the $\mathrm{P}$ value $>0.05$ ( $\mathrm{P}$ value $=0.12$ ). Furthermore, another study conducted by Lienhardt on 1585 adult patients in Africa, Asia, and Latin America between 2003-2008 reported that there was no difference in treatment outcomes between patients receiving OAT-KDT or loose dosage forms, this can be seen from the risk difference of -0.7 with $95 \%$ CI between $-3.0 \%$ to $1.5 \%$ (Lienhardt et al., 2011; Al-Shaer et al., 2017; Sitepu et al., 2018).

The results of the current study showed that through multivariate analysis with logistic regression models, the type of pulmonary TB OAT did not affect the treatment outcome. This can be seen from the p-value of the logistic regression analysis which is smaller than 0.05 . In addition, from the survival analysis to assess the seroconversion time in each type of OAT preparation, it was found that there was no significant difference in the median of survival time from the results of log rank and Cox Regression analysis, this was seen from the $\mathrm{p}$ value $>0.05(\mathrm{p}=0.559)$.

\section{CONCLUSION}

The majority of pulmonary TB patients at Mitra Sejati Amplas General Hospital who received OAT-KDT were mostly in the late elderly age group (56-65 years), female, had a normal body mass index and had no comorbidities. 
There were no significant differences in treatment outcomes and median survival time of seroconversion time in pulmonary TB patients who received OAT-KDT or OAT off dosage form.

\section{ACKNOWLEDGMENTS}

Thank you to the supervisor who has guided to complete this research. And we don't forget to thank the family for the great support to the author.

\section{REFERENCES}

[1] Adane, A. et al. (2020) 'Prevalence and Associated Factors of Tuberculosis among Adult Household Contacts of Smear Positive Pulmonary Tuberculosis Patients Treated in Public Health Facilities of Haramaya District, Oromia Region, Eastern Ethiopia', Tuberculosis Research and Treatment, pp. 1-7. doi: 10.1155/2020/6738532.

[2] Al-Shaer, M. H. et al. (2017) 'Treatment outcomes of fixed-dose combination versus separate tablet regimens in pulmonary tuberculosis patients with or without diabetes in Qatar', BMC Infectious Diseases, 17(118), pp. 1-6. doi: 10.1186/s12879-017-2231-1.

[3] Albanna, A. S. et al. (2013) 'Fixed-dose combination antituberculosis therapy: A systematic review and meta-analysis', European Respiratory Journal, 42(3), pp. 721-732. doi: 10.1183/09031936.00180612.

[4] Ayed, H. Ben et al. (2018) 'Safety and Disease Evolution of Fixed-Dose Combination of Antitubercular Treatment Compared to Separate-Drugs Preparation in Extra-Pulmonary Tuberculosis', Current Pharmacology Reports, 4(6), pp. 415-421. doi: 10.1007/s40495018-0154-1.

[5] Badan Penelitian Dan Pengembangan Kesehatan Kementerian Kesehatan RI (2013) Riset Kesehatan Dasar 2013, Kementrian Kesehatan Republik Indonesia. doi: 1 Desember 2013.

[6] Bahar, A. and Amin, Z. (2017) 'Pengobatan Tuberkulosis Mutakhir', in Setiati, S. et al. (eds) Buku Ajar Ilmu Penyakit Dalam Jilid I Edisi VI. Jakarta: Interna Publishing.

[7] Carroll, C. K. et al. (2016) Medical Microbiology 27th Edition. New York: McGraw-Hill Education.

[8] Djojodibroto, R. D. (2017) Respirologi (Respiratory Medicine). Jakarta: EGC.

[9] Fogel, N. (2015) 'Tuberculosis: A disease without boundaries', Tuberculosis, 95(5), pp. 527-531. doi: 10.1016/j.tube.2015.05.017.

[10] Jacobs, A. J. et al. (2016) 'Antibodies and tuberculosis', Tuberculosis, 101, pp. 102-113. doi: 10.1016/j.tube.2016.08.001.

[11] Kementerian Kesehatan Republik Indonesia (2019) Hasil Utama Riset Kesehata Dasar (RISKESDAS) tahun 2018 [Chief Results of Basic Health Research (RISKESDAS) in 2018]. Jakarta: Kementerian Kesehatan RI. doi: 10.1088/1751-8113/44/8/085201.

[12] Kementerian Kesehatan RI (2016) Peraturan Menteri Kesehatan Republik Indonesias Tentang Penanggulangan Tuberkulosis. Indonesia.

[13] Kendall, K. and Tao, L. (2013) Sinopsis Organ System Pulmonologi. Jakaarta: Karisma Publishing Group.

[14] Lienhardt, C. et al. (2011) 'Efficacy and Safety of a 4-Drug Fixed-DoseCombination Regimen Compared withSeparate Drugs for Treatment of Pulmonary Tuberculosis', Journal American Medical Association, 305(14), pp. 1416-1423. Available at: http://jama.jamanetwork.com/.

[15] Mandell, L. A. and Wunderink, R. (2016) 'Tuberkulosis', in Loscalzo, J. (ed.) Harrison Pulmonologi dan Penyakit Kritis. 2nd edn. EGC, pp. 112-134 
[16] Patel, P. R. (2020) Lecture Notes Radiology 4th Edition. UK: John Wiley \& Sons Ltd.

[17] Rab, T. (2017) Ilmu Penyakit Paru. CV. Trans. Jakarta.

[18] Sitepu, R. et al. (2018) 'Fixed-dose combination versus separate antituberculosis formulations in pulmonary tuberculosis patients: Evaluation of effectiveness and safety', International Journal of Applied Pharmaceutics, 10 (Special Issue 1), pp. 208-210. doi: 10.22159/ijap.2018.v10s1.46.

[19] Subuh, M. et al. (2014) Pedoman Nasional Pengendalian Tuberkulosis. Jakarta: Kementerian Kesehatan RI.

[20] World Health Organization (2016) Global tuberculosis report 2016, WHO. 